For the published paper see:

Artioli, Francesca, Michele Acuto, et Jenny McArthur. 2017. « The water-energy-food nexus: An integration agenda and implications for urban governance ". Political Geography 61, p. 215-23. https://doi.org/10.1016/i.polgeo.2017.08.009

\title{
The water-energy-food nexus: An integration agenda and implications for urban governance
}

\author{
Francesca Artiolia ${ }^{a}$ Michele Acuto $^{b}$, Jenny McArthur ${ }^{b}$ \\ aUniversité Paris-Est, Lab'Urba (EA 3482), UPEC, UPEMLV, EIVP, F-7720 Champs-sur-Marne, France \\ ${ }^{b}$ Department of Science, Technology, Engineering and Public Policy, University College London, 36-38 Fitzroy \\ Square, London W1T 6EY, United Kingdom
}

\begin{abstract}
The water-energy-food nexus has achieved considerable prominence across academic research and policy sectors. The nexus sets an imperative for integrated management and policymaking, centring on the potential trade-offs and complementarities between interdependent water, energy and food systems. Applications of the nexus focus largely on technical or managerial solutions and calls to acknowledge the political dimension of nexus interdependencies have implications for governance at the urban scale. This paper aims to 'urbanise' the nexus agenda and consider the implications of policy integration for urban governance. This examines the nexus in the context of current approaches to urban governance and power relations shaping the provision of water, energy and food in urban areas. Urban infrastructure networks underpin these resource systems and related management systems, although their management tends to operate in silos, with little joint decision-making and planning. Three hypotheses about the interplay between integrative policy framings and urban governance are explored to reconcile integrative policy framings at the urban scale: the appropriation of the nexus narrative by urban governments; reestablishment of political power through integrated management, and implementation of the nexus through smart city approaches. These hypotheses progress the political dimension of the nexus debate and reflect on the role of urban governance in addressing global challenges.
\end{abstract}

\section{Keywords}

Governance, Nexus, Urban sustainability, Resource management, Infrastructure

\section{Introduction}

Pressing environmental sustainability issues have confronted cities for over 25 years, since the institution of Local Agenda 21 the 1992 Rio Earth Summit (Bosworth, 1993). The rapid pace of global urbanisation over the past decade heightens the imperative to transition to more sustainable forms of urban development (Bulkeley, Luque-Ayala, \& Silver, 2014b; Zhang, 2016). The Sustainable Development Goals prioritise urban resilience and sustainability, reinforcing the urban scale as a priority for global and national governance (Parnell, 2016; United Nations, 2015b). Concern has increased in both local governments, global governance actors and the private sector, around the need to secure the availability of water, energy and food through the management of their structural interdependencies (Beddington, 2009; Hoff, 
2011; Muller, 2015). Water, energy and food systems are essential resources on which all human activity relies (Biggs et al., 2015; Smajgl, Ward, \& Pluschke, 2016). Disruptive events such as the crises and the volatility of food prices in 2008, or repeated water and electricity shortages in emerging countries, have led to debate over their interdependence and limits. In this context, the need for cross-sectoral integration of the production and provision of essential resources has garnered greater attention. This cross-sectoral approach, defined as the water-energy-food nexus, has been raised by international organisations and governments as a crucial policy matter (FAO, 2014; Hoff, 2011; Parliamentary Office of Science \& Technology, 2016). The United Nations and World Economic Forum focused heavily on the risks of nexus failures, and the link between resource security and economic growth (Hoff, 2011; United Nations, 2015a). This shift in framing suggests the emergence of a 'nexus approach' in policymaking. As a policy frame, the nexus adopts holistic treatment of interdependent sectors or subsystems (Muller, 2015), gives policymakers the mandate to consider broader interdependencies, and emphasises trade-offs and complementarities between systems (Al-Saidi \& Elagib, 2017).

This nexus approach holds that, instead of focusing on water, energy and food systems separately, governance of resource use and service provision should address the multiple causal pathways through which they interact with each other. The underlying assumption is interdependence across the three systems (the 'nexus'), and in turn, their interactions ultimately affect their availability. Similar to other policy framings such as energy security (Bridge, 2015), the nexus is an integrative imaginary which implies that integrated governance of water, energy and food systems is more advantageous than a siloed approach (Szerszynski \& Galarraga, 2013). This doctrine purports an integration approach because external factors including population growth, environmental change and increasing urbanisation put systems under greater strain. In particular, operationalisation of the nexus seeks to integrate across systems through technological and institutional change (Villamayor-Tomas, Grundmann, Epstein, Evans, \& Kimmich, 2015; Villaroel Walker, Beck, Hall, Dawson, \& Heidrich, 2014). The nexus approach perceives integration as a fundamental step for ensuring resource security in a global context of increasing and competing demands.

While many framings of the nexus contend that there is a coordination failure within existing modes of globalised production and consumption, implementing this approach reveals that it is not value-neutral (Allouche, 2011; Scollon, 2005). This paper discusses the implications of the nexus approach for urban governance, drawing on recent calls to 'politicise the nexus' (Williams, Bouzarovski, \& Swyngedouw, 2014). Growing urbanisation is seen as a key factor in water-food-energy nexus problems, as it shifts land use patterns, the spatial distribution of populations, and concomitant infrastructures and resource flows (Bridge, Bouzarovski, Bradshaw, \& Eyre, 2013). The nexus approach also challenges existing policy configurations on matters such as the supply of water, food, and energy to city dwellers and users (Castán Broto, 2016). Due to their systemic complexity, cities are possibly a critical juncture where the viability, political implementation and challenges arising from nexus thinking will be tested.

This paper constitutes an initial attempt to 'urbanise' the nexus approach to explore the implications for cities, in light of the governance tools and power relations shaping provision of water, energy and food in urban areas. Trends in the growth of cities, albeit varied across regions, have diverged from historical forms of governance and spatial development. New 
flows of international capital, decentralised governance, and economic forces driving agglomeration of particular industry sectors in urban areas all drive new patterns of spatial development (Schmid, Brenner, \& Topalovic, 2016; Seto, Sanchez-Rodriguez, \& Fragkias, 2010). The global trend toward urbanisation presents both challenges and opportunities for sustainability and resource management, and well-informed governance and planning have a central role in addressing these. Growing concentration of populations to urban areas heightens the imperative for the equitable and effective management of interdependent resource systems, with greater criticality around localised failures. Transitions to sustainable urban development can take the form of 'tweaks' to existing systems, or transformative structural changes to confront technological lock-in and systemic inertia (Childers, Pickett, Morgan Grove, Ogden, \& Whitmer, 2014).

The implications of a nexus approach for urban governance have thus far been an object of little systematic attention. Most nexus literature focuses on quantitative modelling of system interactions (Bazilian et al., 2011; Chang, Li, Yao, \& Zhang, 2016; Chhipi-Shrestha, Hewage, \& Sadiq, 2017; Dhakal \& Shrestha, 2017), technological and policy innovations (Brekke \& Brugmann, 2016; Muller, 2015; Schlor, Venghaus, \& Hake, 2017; You, 2016; de Grenade et al., 2016) and regulatory approaches (Larcom \& van Gevelt, 2017). Attention to the nexus at the urban scale connects technical analyses and outputs with urban planning and governance frameworks (Engström et al., 2017; Kenway, 2015; Lenzen et al., 2017), to a more explicit consideration of their underlying governance frameworks - something with which literature on these themes has only begun to grapple. In this sense, we do not wish to understate the important advancement of much recent cutting edge nexus work (Kenway, 2015; McPhearson, Haase, Kabisch, \& Gren, 2016; Scott et al., 2011) but rather argue here for more explicit exploration of the political and governance dimensions of the global and local spatial shifts of urbanisation called into question. The political dimension of multi-scalar water, energy and food systems introduce significant complexity to nexus management (RomeroLankao, McPhearson, \& Davidson, 2017). Our goal is twofold: First, we provide a conceptualisation of the nexus to evaluate the interplay between this policy framing, especially as elaborated at national and international levels, and urban policymaking. We build on public policy theory to conceptualise the water-energy-food nexus approach as a causal story and agenda (Stone, 1989) promoting cross-sectoral integration. Current nexus literature in social sciences in polarised between macro-dynamics and place-specific studies (Stein, Barron, \& Moss, 2014; Williams et al., 2014). Our middle-range approach conceives the nexus approach as a 'policy story' that opens up possibilities for the reconfiguration of existing governance arrangements. Second, we aim to develop a set of hypotheses about the interplay between this approach for cross-sectoral integration and urban governance. In particular, we discuss the urban dilemmas of cross-sectoral integration, regarding power scales, state/market relations and tools of urban governance.

While an integration agenda is often seen by global governance and funding agencies as a panacea to resource crises and risks of cascading failures (Cairns \& Krzywoszynska, 2016), our perspective discusses it as a realm of policy alternatives. Policy integration is not assumed as inherently beneficial, although it should reconcile itself with an understanding of the power relations and institutions shaping policy change. This approach sets an agenda for empirical analysis. Understanding the negotiation of possible integration policies is a crucial matter 
when considering if and how cross-sectoral policies can contribute to universal, equitable and sustainable access to resources.

Our critique of the nexus approach offers insights on models for 'urban integrated management', such as the smart city or resilient city paradigms (Hodson \& Marvin, 2009; Pitrenaite-Zileniene \& Torresi, 2014), as calls for both urban integrated management and infrastructure re-bundling are flourishing in response to 'wicked problems' dominated by interdependencies and spillovers (Frame, 2008; Stirling, 2010). The opportunities for urban intervention are often seen as pertinent for so-called 'wicked problems' (Rittel \& Webber, 1973). Wicked problems are conceived as complex problems with ill-defined boundaries and solutions, subject to multiple competing views across actors and scales, conflicting values, and only partial comprehension of a problem across different actors.

\section{The nexus approach and the urban question}

While initial studies of the water-food-energy approach appeared as early as the 1990s (McCalla, 1997), the nexus has seen unprecedented prominence in the agendas of international organisations over the last decade (Endo, Tsurita, Burnett, \& Orencio, 2017). The extent to which nexus thinking has influenced international debates is evident by looking at the flagship topics put forward by international organisations involved in these three sectors, as well as the proliferation of literature on the matter (Bizikova, Dimple, Swanson, Venema, \& McCandless, 2013; Brekke \& Brugmann, 2016; Carter \& Gulati, 2014; FAO, 2014; Hoff, 2011; Waughray, 2011; World Business Council for Sustainable Development, 2014). Leck, Conway, Bradshaw, and Rees (2015) identify major milestones of this nexuscentric debate: the World Economic Forum in 2008, events run by the German Federal Governments in 2008, Rio+20 Summit in 2012, or the Nexus Declaration delivered to the UN Secretary-General in 2014, for input to the formulation of the Sustainable Development Goals. These international events contributed to cementing the use of nexus thinking beyond academia. Recent academic literature critiques the nexus as a 'buzzword' with vague and subjective meanings, and questions the novelty of the concept (Cairns \& Krzywoszynska, 2016; Wichelns, 2017). Nonetheless, due to the prominence and momentum of the nexus approach within policy circles, the caution expressed in recent literature may not slow down the implementation of the nexus through policy and governance agendas. Therefore this article seeks to re-situate the current nexus debate within urban governance and policymaking, to identify opportunities to operationalise the nexus while maintaining a critical view, treating the concept as a 'matter of concern' (Cairns \& Krzywoszynska, 2016).

The water-food-energy nexus approach has also gained momentum after the food crises in 2007 and 2008, and then in the preparation phase to the Rio+20 conference in 2012 amidst discussions of the integrated aspects of sustainable development. These have led to the consolidation of an 'international dialogue' (Bizikova et al., 2013), involving governmental and non-governmental organisations, which has put nexus thinking solidly amidst sustainability agendas. Academia has also engaged with this thinking, and national research strategies and funding have sometimes targeted the nexus as a critical area for research development. Responses to the nexus have taken the shape of a policy-driven research and funding agenda that spans across disciplines. In the United Kingdom, for instance, the so-called 'perfect storm' challenge raised by the Chief Science Adviser to HM Government (Beddington, 2009) contributed to a research funding agenda that spans several research domains, such as those 
of the Economic and Social Research Council or the Engineering and Physical Sciences Research Council (Parliamentary Office of Science \& Technology, 2016).

One of the defining features of the nexus approach, in policy and academia, is the central imperative for cross-sectoral integration. At the heart of this approach lies a belief in the need to increase cross-system and cross-sectoral analysis, management and planning. In other terms, the nexus approach contends that system interdependence implies a need for integrated management of the three systems. The nexus approach echoes the drive for integration arising from research into infrastructure resilience, urban metabolism and sustainability transitions. However different forms of relationality and potential interventions emerge across these fields. Research into infrastructure resilience elevates urban infrastructures as the 'interface between nature and society' (Monstadt, 2009), and mediating structures for resource flows influencing economic development and social justice. The need to decouple urban growth and increased use of constrained resources links to an agenda to 're-couple' urban systems through infrastructure provision (Hodson, Marvin, Robinson, \& Swilling, 2012), although the prevalence of governance models prioritising shortterm objectives is a major hindrance to this goal (Bolton \& Foxon, 2015). Urban metabolism centres instead on resource flows, based on full life-cycle analysis to address impacts along the supply chain (Castán Broto et al., 2012). Similar to the nexus, urban metabolism is prone to privileging some resource flows at the expense of others (Castán Broto et al., 2012), but can catalyse the production of knowledge to support urban transformations (Guibrunet, Sanzana Calvet, \& Castán Broto, 2016). Sustainability transitions literature focuses on structurally transformative processes, with governance and planning as critical leverage points (McCormick, Anderberg, Coenen, \& Neij, 2013), and an emphasis on reconciling multiscalar resource flows and addressing impacts on social equity (Wachsmuth, Cohen, \& Angelo, 2016). The nexus diverges from these approaches, setting an integrative agenda arising from inter-related systems of resource provision, centred on human needs for water, energy and food. The focus on meeting human needs risks promoting anthropocentric goals at the expense of environmental value (Flint, Kunze, Muhar, Yoshida, \& Penker, 2013). However, it also has potential to produce transformative knowledge of complex interdependent systems, to support an integrative agenda.

The nexus agenda is espoused by diverse international actors ranging from research institutes to business organisations and appears as a consistent feature of nexus discourse. In most policy reports produced since the mid-2000s, this integration narrative asserts intrinsic linkages between water, food and energy systems and therefore the imperative for coordination (Bizikova et al., 2013; Brekke \& Brugmann, 2016; Carter \& Gulati, 2014; FAO, 2014; Hoff, 2011; Waughray, 2011; World Business Council for Sustainable Development, 2014). For example, the production of energy requires water, but the provision of food also requires both water and energy. Following the nexus narrative, these three systems are increasingly under strain as the object of growing and competing demands of changing political-economic conditions, demographic shifts and technological change. Nexus interdependencies pose a risk to both the total availability of resources and equitable access. Indeed, demand for food, energy and water keeps increasing in a context of rapid urbanisation, making the connection between the nexus and urban governance particularly central, although still widely under-scrutinised. Public policies remain predominantly sectorbased - regarding objectives, goals and institutions (Affolderbach \& Schulz, 2016). Sectorbased, or siloed, policymaking produces unintended and potentially negative impacts of one 
sector over the others, and eventually undermines resource availability. Calls to 'break down the silos' have emerged across various environmental policy sectors (Vince, 2015; Vine, 2008). Therefore there is a case for governing the interactions between water, energy and food systems: both the technologies and the governance of the three systems must evolve to improve sustainability and manage risk.

Nonetheless, the urban bases of nexus policy and analysis remain weak. The nexus approach addresses resource governance at the global level. National-level discourse reflects this approach, but less so for local or urban governance. Cities are an inextricable part of nexus interdependencies but remain on the sidelines for research and policy. The nexus narrative leads to two common understandings of the 'urban question'. Firstly, the urbanisation process is a cause of nexus issues, in the present and future. Here, urbanisation, along with other macro trends such as population growth and climate change, is reshaping the conditions within which the water, food and energy systems work and interplay. Urbanisation is one of the forces that contribute to putting resource security at risk. This perspective frames cities in two respects: first, they are the manifestation of agglomeration forces perpetuating continual intensification and growth (Glaeser \& Gottlieb, 2009), and secondly, aggregated demand for resources (Koop \& Van Leeuwen, 2017; Vanham, Mak, \& Gawlik, 2016). The second understanding of the 'urban question' includes the notion that nexus problems take on specific characteristics in cities, and dominates in environmental debates. The intense concentration of populations, consumption activities, critical infrastructures, and social needs in metropolises implies that they are more vulnerable than particular natural hazards than more dispersed rural areas (McPhearson, Andersson, Elmqvist, \& Frantzeskaki, 2015; Sharifi \& Yamagata, 2014). Therefore, the nature of urban areas affects the availability and interdependence of water, food and energy in specific ways.

Despite this understanding of urban areas, urban governance has not received thorough consideration. On the one hand, cities are sites of water, food and energy distribution, consumption and to a lesser extent, production and reuse. Therefore the nexus approach has implications for the assemblage of policy, market and society that are responsible for the production, distribution, use and reuse of these vital resources in cities. On the other hand, cities are both collective and political actors, and city governments are deeply involved in the implementation of policies governing these resources. Nexus interdependencies influence governments as both providers and regulators. In this context, research largely overlooks the interplay between the water-food-energy nexus and urban governance. Alongside studies of nexus management at the urban scale (Kenway \& Lam, 2016; Kenway, Lant, Priestley, \& Daniels, 2011; Serrao-Neumann, Renouf, Kenway, \& Low Choy, 2017), the relation between the global debate on the integrated nexus management, and current modes of urban governance has received limited attention in academic scholarship (Treemore-Spears et al., 2016; Varga, 2016). Urban policy is challenged by the mandate for cross-sectoral integration, as urbanisation integrally influences water-food-energy system interdependencies. Similarly, there is a lack of assessment of how this approach potentially transforms the current modes of provision and consumption of water, food and energy. To counter this imbalance, our discussion of the interplay between the water-food-energy nexus and urban governance builds on research that questions the idea of integration (Williams et al., 2014) and institutional dimensions (Leck et al., 2015) and identifies the crucial importance of power structures shaping these sectors (Allouche, Middleton, \& Gyawali, 2014). This paper considers 
the underpinnings of the nexus approach and implications of treating the political dimensions and urban scale more rigorously. Addressing the implications for urban governance can progress the nexus debate and enable meaningful operationalisation of the nexus through governance and policy.

\section{The imperative to integrate as a causal story}

To-date, criticism from within academia shows the limitations and risks of the nexus approach. Contributions from social scientists working on environmental policy highlight the need to consider the political dimension of nexus interdependencies. Williams et al. (2014) emphasise the important role of open political scrutiny as a strategy of 'politicising the nexus'. The argument maintains that the nexus approach will be ineffective, at best, without a clearer understanding of the political dimension. In the worst case, this oversight risks imposing a managerial logic that neglects less obvious or quantifiable resources, such as biodiversity (Dupar \& Oates, 2012). Similarly, Allouche et al. (2014)[p.23] claims that the potential of the nexus to be a useful 'approach for exploring alternative pathways, rather than a narrative that legitimises existing dominant pathways', and research should address the political economy of the nexus more explicitly. The nexus approach may reproduce existing inequalities in resource allocations and power structures unless research and policy carry a fundamental critique of these very inequalities.

Much of the critique of the nexus also derives from the vagueness of the term and the implicit assumptions about cross-sectoral integration on which it relies. Cairns and Krzywoszynska (2016) recently defined the nexus as a 'buzzword', intended as a term whose power derives from a combination of strong normative resonance and ambiguous meaning. Its power lies in the space of uncertainty left between the ambiguity of the concept and the normative imperative to integrate. Also, the nexus approach incorporates the assumption that integration is inherently beneficial. In doing so, it might normatively push forward generic policy recommendations espousing 'integration', overlooking place-specific needs and configurations and, therefore, running the risk of having null or even harmful effects. The suitability of the nexus across all contexts is questioned: integration can create even greater complexity and further hinder decision-making for policy and investments (Wichelns, 2017).

Given the pervasiveness of the nexus agenda in the policy realm, we suggest the nexus approach as an object of research per se, to address the political dimensions and discuss implications for urban governance. Building on these claims for more political and historical accounts of the nexus, we then turn to public policy theory to conceptualise the water-foodenergy nexus as a policy agenda, backed by a causal story promoting cross-sectoral integration. Causal stories are crucial in the formulation of policy agendas and to determine the alternative solutions put forward (Stone, 1989). They demonstrate the interdependencies between phenomena and create the imperative for a policy response.

By treating the nexus as a policy agenda, we aim to provide a middle-range conceptualisation which is currently missing in the nexus literature. Theoretical and empirical approaches tend toward scalar extremes, between the analysis of macro-dynamics and place-specific studies (Stein et al., 2014; Williams et al., 2014). 
The macro approach to the nexus conceptualises the approach as an expression of more general transformations of the global political economy and political ecology. Akin to structuralist sensibilities, such a perspective considers the emergence and the success of the nexus approach as the result of the ongoing neoliberalisation of capitalism (Allan, Keulertz, \& Woertz, 2015). Indeed, one of the constitutive elements of the neoliberal project is the commodification of natural resources. In this view, the water-food-energy nexus is both a component and a contribution to this trend: embedded in the reproduction of capitalism, and contributing to the expansion of market as the primary mode of regulation. Williams et al. (2014) shed light on the institutionalisation of water requirements for energy production in political and technical configurations that make them both environmentally unsustainable and linked to structural inequalities of access. However, these two resources, which are essential to the reproduction of capitalistic accumulation, are under strain and their interdependency creates greater risks for the security of supply (Pittock, Orr, Stevens, Aheeyar, \& Smith, 2015). In this perspective, the nexus is a response offered within a capitalist system to ensure the ongoing availability of natural resources, and to address the nexus crises that threaten its reproduction. The nexus approach intertwines with the structure of the global political economy and ecology and, if not explicitly challenged, can be appropriated a tool to reproduce current power structures and inequalities (Allouche, Middleton, \& Gyawali, 2015).

A bottom-up approach to the nexus takes the opposite stance, analysing the nexus from the perspective of actors that work with resource interdependence and, eventually, integrated management (Allouche et al., 2014; Stein et al., 2014). This approach is grounded in specific temporal and geographical contexts. The water, food and energy sectors and their interdependencies exist in profoundly different configurations of state-market-technical assemblages, across regions and time scales. The meanings assigned to issues of interdependence and integration vary significantly. The three sectors are never completely isolated in the view of those working with them, but their interdependence was conceived and labelled in diverse and idiosyncratic ways. This research perspective, therefore, does not address the nexus approach, intended as a new tool and a norm developed by experts in a neoliberal world. On the contrary, it favours the study of the politics, meanings and practices across a plurality of nexus(es), and their implications for social and environmental justice. Politicising the nexus implies the adoption of a pragmatist approach (Stein et al., 2014), that values 'bottom-up ways of knowing the relationship between water, food and energy' (Allouche et al., 2014) as much as decentralised governance and experimentation.

These two approaches are crucial to an understanding of the water-food-energy nexus that goes beyond that of an ambiguous policy 'buzzword' (Cairns \& Krzywoszynska, 2016), to support transformative research. Neither approach can address the relations between the nexus and urban governance entirely. Following a macro approach, the water, food and energy nexus becomes the expression of the transformation of capitalism, with limited agency assigned to urban political institutions and actors. While nexus management at the urban scale is in alignment with capitalist urbanisation (Harvey, 1985), by securing access to essential resources to support economic stability and development, it does not provide a complete account of critical processes for urban governance. Specifically, the formation of policy agendas emerges from diverse governance actors, including supra-national city networks (Acuto, 2013a) and circuits of knowledge developed by urban policy fora at both 
local and international scales (McCann, 2010). Thus, for cities, the consolidation of a nexus approach to the management of natural resources at the global level might be seen as an exogenous process, whose structural features are largely beyond the urban reach. Critical local capacities for action, existing governance arrangements and innovations are displaced in this analytical lens.

Conversely, the bottom-up approach recognises the relevance of local arrangements. By stressing the existence of different interdependencies and vernacular types of integrated management of natural resources, however, this tends to overlook the success and global prominence of the nexus as an emerging mandate for resource management. Therefore, while in this perspective cities can be researched as one of the places of localised nexus governance, the nexus approach itself tends to be left aside. Both approaches are therefore problematic not just in theory but also for a well-informed policy practice.

Our strategy to address this tension stands between macro-dynamics and local contingency, aiming to develop a middle-range approach that analyses the approach as a causal narrative to frame policy and a policy agenda with relative autonomy. In particular, we can consider the nexus approach as a narrative that promotes policy change. Policy scholars debate the role of discourses, stories, and ideas in public policy and governance (Campbell, 2002; Hall, 1993; Schmidt, 2015). Ideas and discourses contribute to policy change in different ways, ranging from major shifts in the cognitive paradigms and worldviews to the partial reframing of existing policy solutions. In this form of policy change, driven by re-conceptualisation and reframing, construction of causal stories plays a crucial role. Causal stories transform the boundary conditions of a policy problem, to advance them onto public and political agendas (Stone, 1989). Following this literature, the nexus is a socially- and politically-constructed causal narrative that transforms the condition of the water, food and energy systems into the policy problem of governing the nexus.

This production of a policy agenda through the nexus narrative operates through the identification of chains of causes, consequences and then solutions. Causal chains allow for the public definition of a desirable future, seen as the most rational manner to deal with the present as much as with legacies of the past. Causal stories have various political impacts (Jasanoff, 2005). Firstly, they define the range of possible policy options for the future and therefore exclude alternative possibilities. Secondly, they can either challenge or protect an existing social order: Identifying causality can lay responsibility with particular actors, compelling them to change. They can also lead to the identification of some actors as fixers of the problem (Stone, 1989). Lastly, causal narratives can be challenged by contradictory framings of the problem, causal relationships and possible solutions, reflecting the diversity of those involved in their development (or destruction).

In this respect, the nexus causal story provides an interpretation of the past, identifies the causes of the (unsatisfactory) present condition and, through this, contributes to identifying the increased integration across the three systems as the most practical solution to this condition. As suggested above, the nexus agenda posits that integrated management is the panacea to problems of availability, access, and provision of essential human resources. The interdependence of the water, food and energy systems being the problem, integrated management is the solution. Integrated management employs a combination of governance 
and technological changes to achieve this. Indeed, commonly expected changes include increasing awareness of interdependencies through engaging stakeholders, increasing policy coordination and harmonisation, the promotion of cross-sectoral and cross-departmental approaches, and promotion of technological innovation and improve resource productivity (Bizikova et al., 2013).

This conceptualisation of the water-food-energy nexus as a causal story helps to analyse of the interplay between this policy approach elaborated at the international level and the existing governance arrangements in cities. As a policy artefact, this causal narrative has autonomy from both the transformations of capitalism and institutionalised local regulations. It is exogenous to urban policies, can be appropriated by actors and organisations at the urban scale, and interacts with the existing governance arrangements that deal with interdependence and integrated management. In other terms, the nexus approach as a story opens up possibilities for the reconfiguration of existing policies. Therefore, we contend that global political economy and ecology, and place-specific configurations shape urban nexus policies, as shown by existing literature, but also by negotiations and struggles over meanings, means and expected outputs of integrated management. The remainder of the paper formulates hypotheses about urban nexus policies, intended as policies for cross-sectoral integration and integrated management in urban governance.

Bringing the nexus into the urban context heavily implicates the governance of urban infrastructure systems as the primary conduits shaping and enabling resource flows. Urban infrastructure systems are intrinsic to the urban nexus as the 'architecture of circulation' (Larkin, 2013) for resource flows, patterns of production and consumption, and are often the centre of political contestation over environmental objectives (Bulkeley, Castán Broto, \& Maassen, 2014a; Hodson \& Marvin, 2011; Varga, 2016). Beyond the large-scale physical systems, infrastructures also comprise socio-material, hybrid configurations which can be adapted and renewed (Furlong, 2011; Moss, 2016). Adequate and efficient provision of infrastructure services to support everyday life in cities is a global issue, and the entrenched forms of planning, procuring and financing infrastructure investment can act against broader goals for environmental sustainability and resilience (Helm, 2016; Malekpour, Brown, \& de Haan, 2015; Roelich et al., 2015). Urban governance is an important mechanism to support transitions to more sustainable and equitable forms of infrastructure provision (Bulkeley, 2005; Frantzeskaki, Jhagroe, \& Howlett, 2016; Jeffrey et al., 2011).

\section{Possible impacts of integrated management as a new paradigm for urban governance}

The nexus narrative tends to imply causal chain that goes from a set of pre-conditions (the interdependence of the water-food-energy system) to the promotion of a form of collective political intervention for cross-sectoral interventions and integrated management. The construction of causality chains in policy narratives contributes to promoting the issue on government agendas, as well as defining legitimate solutions and excluding alternatives. For example, the broken windows theory in criminology puts forward a causal narrative linking perceived disorder in the urban environment with human behaviour and a greater chance of crime or antisocial behaviour, putting forward the agenda for an alternative approach to policing (Wilson, 1982). By considering the political effects of causal stories, this last section focuses on how the water-food-energy nexus approach interplays with urban governance, through three hypotheses about the nexus approach and urban nexus policies. These 
consider the relevant scale of oversight and intervention for nexus governance, potential to re-work state/market relations in public service provision and available tools for crosssectoral integration. These hypotheses point out the realms of possibility and contention of urban policies for cross-sectoral integration and integrated management. Exploration of the three hypotheses raises possible directions for research into the urban nexus.

\subsection{Scales of cross-sectoral integration: urban governments appropriating nexus management?}

The first hypothesis concerns the power scale in policies for cross-sectoral integration and integrated management. Historically, conceptualisation of conflicts and spillovers across sectors took place at the level of the nation-state. However, both the multiplication of wicked problems and erosion of the nation-state have left room for alternative scales of crosssectoral coordination. Over the past fifteen years, urban research has shown the increased political and economic relevance of cities, in the context of rapid urbanisation (Zhang, 2016). Cities and metropolitan areas are critical sites of economic production and innovation, due to the transformation of capitalistic accumulation as much as the transformation of national economic development strategies (Brenner, 2011). Cities are reinforced as political authorities and levels of government, thanks to decentralisation reforms, increased economic relevance and the emergence of new political leaders at the urban and metropolitan level (Le Galès \& Crouch, 2012; Le Galès, 2002). In this context, cities have asserted themselves as the optimal scale for the elaboration and implementation of policies and opportunities for policy innovation. For wicked problems and emerging policies to address them, cities have often taken the lead, such as the case for climate change mitigation (Acuto, 2013b). Though national policies can affect the agency of urban governments, some cities have imposed themselves as sites of policy experimentation, and new city networks have consolidated around this issue.

The water-food-energy nexus problem is a wicked problem and emerging policy issue. Similar to climate change mitigation, therefore, it can be a realm of extensive innovation and intervention for urban policies. Indeed, the emergence of new urban initiatives is encouraged by the lack of highly institutionalized policies, such as those governing more established policy areas such as housing. Furthermore, beyond individual city initiatives, nexus policies may emerge from the same organisational constellations formed by international organisations, and city networks that promote urban policies for climate change mitigation. As discussed above, the nexus approach has mainly its origins in international institutions and anchors in the global politics of natural resource management. City networks can play an instrumental role in the appropriation this nexus approach. A recent report and policy briefs from ICLEI Local Governments for Sustainability constitutes a relevant claim for a more active role of cities in the articulation of nexus problems and solutions (Brekke \& Brugmann, 2016). These programmatic documents affirm that cities are the scale to address both local and global resource constraints. In this perspective, nexus problems are urban problems. Cities are important actors for nexus policies, from which nexus can evolve beyond the urban scale.

Given the rise of cities as collective actors and their implication in wicked problems, our first hypothesis is that urban governments appropriate the nexus narrative, beyond its origin in international organisations. Cities, as both political actors and institutional configurations, can elaborate specific understandings of the water-food-energy nexus and urban solutions for 
cross-sectoral integration. In this perspective, cities and city networks are collective actors that can advocate for and contribute to the production, management and distribution of resources.

\subsection{State/market relations: integrated management as a re-establishment of political power?}

The second hypothesis concerns the nexus approach and the reworking of state/market relations in urban governance. The ongoing extension of market-based forms of regulation of the society has not left cities untouched. Beyond the debate about the nature and the scale of neoliberal urban policies, there is agreement that economic globalisation, financialisation, the dismantling of Fordist agreements and the introduction of capitalist systems in previously socialist countries (Perkins, 2009; Viitanen \& Kingston, 2014) mean that market actors are more relevant in the production and provision of urban infrastructure. Trends have been observed of market-driven privatisation and unbundling of urban utilities and infrastructure (Bridge, 2014; O'Brien \& Pike, 2017; Rutherford, 2008). Local monopolies have been liberalised with a subsequent multiplication of providers, while mundane affairs such as waste management have become a highly valuable business for global market players (Coutard, 2010). In the realm of networked infrastructure, the splintering urbanism thesis (Graham \& Marvin, 2001) purports the decreased capacity of city governments to coordinate this fragmented landscape of infrastructure and service provision. More generally, the policydriven reworking of state/market relations in the provision of urban policies has led to a decreased capacity for local political actors to coordinate, control and steer market actors whose interests and strategies are often far beyond the governmental reach (Raco, 2011).

Following the assessment of a reduced role for city governments to coordinate and steer market actors, who play a greater role in the provision of urban services, our second hypothesis outlines out two alternative directions for nexus policies. Firstly, as the nexus approach postulates increasing coordination across sectors, city governments may appropriate this to reaffirm political power and control. Transition to new institutional forms, such as Multi-Utility Service Companies (MUSCos), is contended to reconfigure urban service provision toward long term sustainability and facilitate cross-sector efficiency (Knoeri, Steinberger, \& Roelich, 2016; Roelich, Steinberger, \& Knoeri, 2011, pp. 185-193). In this instance, the nexus approach becomes a policy tool in which cross-sectoral coordination is sought not only to reduce inefficiency and coordination problems but also to increase the capacity of city governments to steer market actors and the nature and extent of service provision. However re-bundling of resource governance does not guarantee to reverse the wider effects of fragmentation according to the 'splintering urbanism' thesis, and processes to reverse this must also take place within the uneven power structures that drove the fragmentation in the first instance (Graham, 2000). Also, Luque-Ayala and Marvin (2016) show how the implementation of smart technologies can result in 'partial and selective re-bundling of networks and urban space', influenced by logics of network control. Fragmentation of urban governance also transformed sustainability discourse: coalitions of international agencies, academic and private sector actors increasingly influence urban politics, and continue to generate 'competing environmental logics' (Hodson, 2017) of which the nexus is an example. These logics, which include urban resilience, low carbon transitions, smart urbanism and urban experimentalism, are also vulnerable to being used to promote narrow conceptions of urban sustainability. 
The aforementioned risks of adopting the nexus to re-establish political power suggest a possible alternative trajectory, which follows the thesis of the nexus approach as a Trojan horse for neoliberal policies. Several critiques of the water-food-energy nexus approach emphasise that nexus solutions are so far efficiency-driven, based on technological change and managerial rationalization (Cairns \& Krzywoszynska, 2016; Williams et al., 2014). Because of the techno-managerial rationale and solutions, this nexus approach is primarily marketbased. Political critiques of the promotion of efficiency-based solutions and links with a wider neoliberal project are sidelined, therefore giving an opportunity for market-based reforms. In this view, cross-sectoral coordination links with the imperative to mitigate potential nexus crises of resource availability, while sustaining economic accumulation. The nexus approach may also be appropriated by, and provide significant benefit to, private sector actors offering managerial and technological solutions for cross-sectoral coordination.

\subsection{The nexus as the smart city? blending urban tools for integrated management}

The water-food-energy nexus is one of numerous policy approaches promoting cross-sectoral coordination through techno-managerial solutions. Coordination is a long-standing doctrine in administration and government. In the most general sense, the doctrine holds that all or many parts of executive government should interconnect, complement one another, and pool relevant information ( $\mathrm{Hood}, 2005)$. Over recent decades, the issue of coordination (sometimes labeled joined-up government, as in the UK case) has regained prominence (O'Flynn, Blackman, \& Halligan, 2013). It links with the critique of a delivery chain of public services in 'silos', and goals of improved efficiency, but also offering a unique view of government to citizens. The nexus also constitutes a post-New Public Management solution. New Public Management, particularly the earlier versions, tend toward disaggregation, increased autonomy and outsourcing of government. New forms of cross-sectoral coordination are promoted as a new holistic approach to re-establish coordination of goals and means in a fragmented system of public service delivery. Secondly, the problem of coordination in government links with the transformation of policy problems. In the realm of natural resource management, approaches such as Integrated Coastal Management or Integrated Water Cycle Management rely on the principle of establishing coordination across 'usually separated' sectors and scales.

Multiple pressures for coordination apply at the level of local and city governments. For instance, place-based approaches to social and environmental issues in urban areas have grown in relevance during the last decades (Barnett \& Parnell, 2016; John, 2010), as the main innovations in addressing urban problems such as poverty and exclusion. New institutional forms for cross-sector infrastructure service provision may also attempt to reconcile dependencies and improve resource efficiency (Knoeri et al., 2016). Furthermore, the government of cities is also a relevant field for cross-sectoral management based upon ICT solutions. In government and public administration, the notion of joining up government by new information architecture is central to contemporary ideas about integration, where ICT and internet-based solutions counter silo thinking ( $\mathrm{Hood}, 2005)$. The link between an integrative agenda and the notion of the smart city is well-established and has gained political attention (Batty et al., 2012; Neirotti, De Marco, Cagliano, Mangano, \& Scorrano, 2014). The smart city model usually refers to the application of information and communication technologies to optimise resource use, while allowing for increased transparency and 
participation, through a systemic coordination across different spaces and sectors of the urban realm.

Given the rise of cross-sectoral coordination as a holistic policy doctrine, our last hypothesis holds that the urbanisation of the nexus approach is part of a more comprehensive trend toward integrated management, among which the smart city is by far the more encompassing and dynamic. In doing so, the water food-energy approach also contributes to reinforcing integrated management as an emerging paradigm in urban governance.

\section{Where next for the urban nexus?}

This paper had the dual goal of extending the debate opened by social scientists about the politics of the water-food-energy nexus approach, and also to urbanise the debate. This shift from a global and techno-scientific debate (Herrera, 2003; Jasanoff, 2016) toward a political and urban understanding of the water-food-energy nexus follows two strategies. One consists of taking the nexus out of the 'nexus' debate about global resources management and resituating it in broader political debates about the transformations of government. If considered as an agenda for cross-sectoral integration, the water-food-energy nexus approach echoes many policy framings that have emerged over recent decades. Beyond the sectors of water, energy and food, much can be learnt from policy experiments in joined-up government, and the outcomes and challenges for democratic accountability, distribution of the expertise and capacity to coordinate. The second strategy shifts the scale of the nexus debate from the global to the urban scale. Here, again, the nexus echoes other experiences of urban policies for wicked problems. As an approach for integrated management, it has parallels with more successful city models, such as the smart city or the sustainable city, that also promote urban integrated management as policy and governance paradigm.

These strategies for reframing the water-food-energy nexus progress the nexus debate by considering it as a driver for policy change that structures alternatives, rather than as a panacea or danger. In this perspective, directions for further research arise around the question of which actors have authority and capacity for integrated management, and how they conceive the problems of the water, food and energy sectors. The financial, material and political resources utilised, and tools for policy change will influence incumbent policy regimes.

\section{Funding sources}

This work was supported by the Engineering and Physical Sciences Research Council (UK) Research Project: Water Energy Food: WEFWEBs [grant number EP/N005600/1] under Work Package 3: Nexus governance. Actor mapping and stakeholder analysis.

\section{References}

Acuto, 2013a M. Acuto

City leadership in global governance

Global Governance, 19 (2013), pp. 481-493

Acuto, 2013b M. Acuto

The new climate leaders?

Review of International Studies, 39 (2013), pp. 835-857

Affolderbach and Schulz, $2016 \quad J$. Affolderbach, C. Schulz

Mobile transitions: Exploring synergies for urban sustainability research 
Urban Studies, 53 (2016), pp. 1942-1957

Al-Saidi and Elagib, $2017 \quad$ M. Al-Saidi, N. Elagib

Towards understanding the integrative approach of the water, energy and food nexus

Science of the Total Environment, 574 (2017), pp. 1131-1139

Allan et al., $2015 \quad$ T. Allan, M. Keulertz, E. Woertz

The water-energy-food nexus: An introduction to nexus concepts and some conceptual and operational problems

International Journal of Water Resources Development, 31 (2015), pp. 301-311

Allouche, $2011 \quad J$. Allouche

The sustainability and resilience of global water and food systems: Political analysis of the interplay between security, resource scarcity, political systems and global trade

Food Policy, 36 (2011), pp. S3-S8

Allouche et al., 2014

J. Allouche, C. Middleton, D. Gyawali

Nexus Nirvana or Nexus Nullity? A dynamic approach to security and sustainability in the water-energy food nexus

(2014) Working Paper 63 STEPS Centre Brighton, United Kingdom

Allouche et al., 2015

J. Allouche, C. Middleton, D. GyawaliTechnical veil, hidden politics:

Interrogating the power linkages behind the nexus

Water Alternatives, 8 (2015), pp. 610-626

Barnett and Parnell, 2016

C. Barnett, S. Parnell

Ideas, implementation and indicators: Epistemologies of the post-2015 urban agenda

Environment and Urbanization, 28 (2016), pp. 87-98

Batty et al., 2012

M. Batty, K. Axhausen, G. Fosca, A. Pozdnoukhov, A.Bazzani, M. Wachowicz

Smart cities of the future

European Physical Journal: Special Topics, 214 (2012), pp. 481-518

Bazilian et al., 2011

M. Bazilian, H. Rogner, M. Howells, S. Hermann, D.Arent, D. Gielen, et al.

Considering the energy, water and food nexus: Towards an integrated modelling approach

Energy Policy, 39 (2011), pp. 7896-7906

Beddington, 2009

J. Beddington

Food, energy, water and the climate: A perfect storm of global events?

Technical Report Government Office for Science (2009)

Biggs et al., 2015

E.M. Biggs, E. Bruce, B. Boruff, J.M.A. Duncan, J. Horsley, N. Pauli, et

Sustainable development in the water-energy food nexus: A perspective on livelihoods

Environmental Science \& Policy, 54 (2015), pp. 389-397

Bizikova et al., 2013 
L. Bizikova, R. Dimple, D. Swanson, H. Venema, M.McCandless

The Water-Energy-Food Security Nexus: Towards a practical planning and decision-support framework for landscape investment and risk management Technical Report The International Institute for Sustainable Development Winnipeg, Manitoba, Canada (2013)

Bolton and Foxon, 2015

R. Bolton, T. Foxon

Infrastructure transformation as a socio -technical process - implications for the governance of energy distribution networks in the UK

Technological Forecasting and Social Change, 90 (2015), pp. 538-550

Bosworth, 1993

T. Bosworth

Local authorities and sustainable development

European Environment, 3 (1993), pp. 13-17

Brekke and Brugmann, 2016

K. Brekke, J. Brugmann

Operationalizing the urban nexus: Increasing the productivity of cities and urbanized nations

F. Dodds, J. Bartram (Eds.), The water, food, energy and climate Nexus:

Challenges and an agenda for action chapter 7, Routledge(2016)

Brenner, 2011

N. Brenner

New state Spaces: Urban governance and the rescaling of statehood

Oxford University Press, Oxford, United Kingdom (2011)

Bridge, 2014

G. Bridge

Resource geographies II: The resource-state nexus

Progress in Human Geography, 38 (2014), pp. 118-130

Bridge, 2015

G. Bridge

Energy (in)security: World-making in an age of scarcity

Political Geography, 181 (2015), pp. 328-339

Bridge et al., 2013

G. Bridge, S. Bouzarovski, M. Bradshaw, N. Eyre

Geographies of energy transition: Space, place and the low-carbon economy

Energy Policy, 53 (2013), pp. 331-340

Bulkeley, 2005

H. Bulkeley

Reconfiguring environmental governance: Towards a politics of scales and networks

Political Geography, 24 (2005), pp. 875-902

Bulkeley et al., 2014a

H. Bulkeley, V. Castán Broto, A. Maassen

Low-carbon transitions and the reconfiguration of urban infrastructure

Urban Studies, 51 (2014), pp. 1471-1486

Bulkeley et al., 2014b 
H. Bulkeley, A. Luque-Ayala, J. Silver

Housing and the (re)configuration of energy provision in Cape Town and São

Paulo: Making space for a progressive urban climate politics?

Political Geography, 40 (2014), pp. 25-34

Cairns and Krzywoszynska, 2016

R. Cairns, A. Krzywoszynska

Anatomy of a buzzword: The emergence of 'the water-energy-food nexus' in UK natural resource debates

Environmental Science \& Policy, 64 (2016), pp. 164-170

\section{Campbell, 2002}

J. Campbell

Ideas, politics, and public policy

Annual Review of Sociology, 28 (2002), pp. 21-38

Carter and Gulati, 2014

S. Carter, M. Gulati

Climate change, the food energy water nexus and food security in South

Africa

Understanding the Food Energy Water Nexus. Technical Report WWF-SA

(2014)

\section{Castán Broto, 2016}

V. Castán Broto

Urban infrastructure landscapes and the politics of dwelling

Nexuses of the urban: Interactions between water, energy, and food provision

for sustainable cities (2016)

Brighton, United Kingdom

\section{Castán Broto et al., 2012}

V. Castán Broto, A. Allen, E. Rapoport

Interdisciplinary perspectives on urban metabolism

Journal of Industrial Ecology, 16 (2012), pp. 851-861

\section{Chang et al., 2016}

Y. Chang, G. Li, Y. Yao, L. Zhang

Quantifying the water-energy food nexus: Current status and trends

Energies, 9 (2016), pp. 1-17

\section{Chhipi-Shrestha et al., 2017}

G. Chhipi-Shrestha, K. Hewage, R. Sadiq

Water-energy-carbon nexus modelling for an urban water system: A system dynamics approach

Journal of Water Resources Planning and Management, 143 (6)(2017), pp. 1-11

\section{Childers et al., 2014}

D. Childers, S. Pickett, J. Morgan Grove, L. Ogden, A.Whitmer

Advancing urban sustainability theory and action: Challenges and opportunities

Landscape and Urban Planning, 125 (2014), pp. 320-328

\section{Coutard, 2010}

O. Coutard

The rise of post-networked cities in Europe? Recombining infrastructural, ecological and urban transformations in low carbon transitions 
H. Bulkeley, V. Castan Broto, M. Hodson, S. Marvin (Eds.), Cities and low carbon

transitions, Taylor \& Francis, Abingdon, United Kingdom(2010), pp. 107-125

Dhakal and Shrestha, 2017

S. Dhakal, A. Shrestha

Optimizing water-energy-carbon nexus in cities for low carbon development

S. Dhakal, M. Ruth (Eds.), Creating low carbon cities, Springer(2017), pp. 29-42

Dupar and Oates, 2012

M. Dupar, N. Oates

Getting to grips with the water-energy-food 'nexus' (2012)

http://cdkn.org/2012/04/getting-to-grips-with-the-water-energyfood-nexus/

Endo et al., 2017

A. Endo, I. Tsurita, K. Burnett, P. Orencio

A review of the current state of research on the water, energy, and food nexus

Journal of Hydrology: Regional Studies, 11 (2017), pp. 20-30

Engström et al., 2017

R. Engström, M. Howells, G. Destouni, V. Bhatt, M.Bazilian, H. Rogner

Connecting the resource nexus to basic urban service provision - with focus on water-energy interactions in New York City

Sustainable Cities and Society, 31 (2017), pp. 83-94

FAO, 2014 FAO

The Water-Energy-Food Nexus. A new approach in support of food security and sustainable agriculture

Technical Report Food and Agriculture Organization of the United Nations Rome (2014)

Flint et al., 2013

C. Flint, I. Kunze, A. Muhar, Y. Yoshida, M. Penker

Exploring empirical typologies of human-nature relationships and linkages to the ecosystem services concept

Landscape and Urban Planning, 120 (2013), pp. 208-217

Frame, 2008 B. Frame

'Wicked', 'Messy', and 'Clumsy': Long-Term frameworks for sustainability

Environment and Planning C: Government and Policy, 26 (2008), pp. 1113-1128

Frantzeskaki et al., 2016

N. Frantzeskaki, S. Jhagroe, M. Howlett

Greening the state? The framing of sustainability in Dutch infrastructure governance

Environmental Science \& Policy, 58 (2016), pp. 123-130

Furlong, 2011

K. Furlong

Small technologies, big change: Rethinking infrastructure through STS and

geography

Progress in Human Geography, 35 (2011), pp. 460-482

Glaeser and Gottlieb, 2009

E. Glaeser, J. Gottlieb

The wealth of cities: Agglomeration economies and spatial equilibrium in the United States 
Journal of Economic Literature, 47 (2009), pp. 983-1028

Graham, 2000

S. Graham

Constructing premium network spaces: Reflections on infrastructure networks and contemporary urban development

International Journal of Urban and Regional Research, 24 (2000), pp. 183-200

Graham and Marvin, 2001

S. Graham, S. Marvin

Splintering Urbanism: Networked infrastructures, technological mobilities and the urban condition

Routledge, London, United Kingdom (2001)

de Grenade et al., 2016

R. de Grenade, L. House-Peters, C.A. Scott, B.Thapa, M. Mills-

Novoa, A. Gerlak, et al.

The nexus: Reconsidering environmental security and adaptive capacity

Current Opinion in Environmental Sustainablility, 21 (2016), pp. 15-21

\section{Guibrunet et al., 2016}

L. Guibrunet, M. Sanzana Calvet, V. Castán Broto

Flows, system boundaries and the politics of urban metabolism: Waste management in Mexico City and Santiago de Chile

Geoforum (2016), 10.1016/i.geoforum.2016.10.011

Hall, 1993 P. Hall

Policy paradigms, social learning, and the state: The case of economic policymaking in Britain

Comparative Politics, 25 (1993), pp. 275-296

Harvey, 1985

D. Harvey

The urbanization of capital

Johns Hopkins University Press, Baltimore, MD (1985)

$\underline{\text { Helm, } 2016}$

D. Helm

Infrastructure: Why it is under provided and badly managed

Oxford Review of Economic Policy, 32 (2016), pp. 343-359

Herrera, 2003

G. Herrera

Technology and international systems

Millenium: Journal of International Studies, 32 (2003), pp. 559-593

Hodson, 2017

M. Hodson

Intensifying or transforming sustainable cities? Fragmented logics of urban environmentalism

Local Environment (2017), 10.1080/13549839.2017.1306498

Hodson and Marvin, 2009

M. Hodson, S. Marvin

'Urban ecological security': A new urban paradigm?

International Journal of Urban and Regional Research, 33 (2009), pp. 193-215

Hodson and Marvin, 2011 
M. Hodson, S. Marvin

The politics of governing cities, infrastructures and resource flows: Spaces of reproduction or reconfiguration?

Geographica Helvetica, 66 (2011), pp. 108-114

Hodson et al., 2012

M. Hodson, S. Marvin, B. Robinson, M. Swilling

Reshaping urban Infrastructure: Material flow analysis and transitions

analysis in an urban context

Journal of Industrial Ecology, 16 (2012), pp. 789-800

Hoff, 2011 H. Hoff

Understanding the nexus

Background paper for the Bonn2011 Conference: The water, energy, and food security nexus, Stockholm Environment Institute, Stockholm(2011)

Hood, 2005 C. Hood

The idea of joined-up government: A historical perspective

Joined-up government chapter 2, British Academy, London (2005), pp. 19-42

Jasanoff, 2005

S. Jasanoff

Restoring reason. Causal narratives and political culture

B. Hutter, M. Power (Eds.), Organizational encounters with risk, Cambridge

University Press (2005), pp. 209-232

Jasanoff, 2016

S. Jasanoff

The ethics of Invention: Technology and the human future

W.W. Norton (2016)

Jeffrey et al., 2011

P. Jeffrey, M.B. Beck, M. Thompson, S. Ney, D. Gyawali, P. Jeffrey

On governance for re-engineering city infrastructure

Engineering Sustainability: Proceedings of the Institution of Civil

Engineers, 164 (2011), pp. 129-142

John, 2010 F. John

Place and place-making in cities: A global perspective

Planning Theory \& Practice, 11 (2010), pp. 149-165

Kenway, 2015

S. Kenway

Management of the urban energy-water nexus

J. Pittock, K. Hussey, S. Dovers (Eds.), Climate, energy and water: Managing

trade-offs, seizing opportunities, Cambridge University Press, New York (2015),

pp. 141-154

Kenway and Lam, 2016

S. Kenway, K. Lam

Quantifying and managing urban water-related energy use systemically: Case study lessons from Australia

International Journal of Water Resources Development, 32 (2016), pp. 379-397

Kenway et al., 2011

S.J. Kenway, P.A. Lant, A. Priestley, P. Daniels

The connection between water and energy in cities: $A$ review 
Water Science \& Technology, 63 (2011), pp. 1983-1990

Knoeri et al., 2016

C. Knoeri, J. Steinberger, K. Roelich

End-user centred infrastructure operation: Towards integrated end-use service delivery

Journal of Cleaner Production, 132 (2016), pp. 229-239

Koop and Van Leeuwen, 2017

S. Koop, C. Van Leeuwen

The challenges of water, waste and climate change in cities

Environment, Development and Sustainability Development, 19 (2)(2017),

pp. 385-418

Larcom and van Gevelt, 2017

S. Larcom, T. van Gevelt

Regulating the water-energy-food nexus: Interdependencies, transaction costs and procedural justice

Environmental Science \& Policy, 72 (2017), pp. 55-64

Larkin, 2013

B. Larkin

The politics and poetics of infrastructure

Annual Review of Anthropology, 42 (2013), pp. 327-343

Le Galès, 2002

P. Le Galès

European cities

Oxford University Press (2002)

Le Galès and Crouch, 2012

P. Le Galès, C. Crouch

Cities as national champions?

Journal of European Public Policy, 19 (2012), pp. 405-419

Leck et al., 2015

H. Leck, D. Conway, M. Bradshaw, J. Rees

Tracing the water-energy-food Nexus: Description, theory and practice

Geography Compass, 9 (2015), pp. 445-460

Lenzen et al., 2017

M. Lenzen, A. Geschke, A. Malik, J. Fry, J. Lane, T.Wiedmann, et al.

New multi-regional input-output databases for Australia - enabling timely and flexible regional analysis

Economic Systems Research, 29 (2017), pp. 275-295

Luque-Ayala and Marvin, 2016

A. Luque-Ayala, S. Marvin

The maintenance of urban circulation: An operational logic of infrastructural control

Environment and Planning D: Society and Space, 34 (2016), pp. 191-208

Malekpour et al., 2015

S. Malekpour, R. Brown, F. de Haan

Strategic planning of urban infrastructure for environmental sustainability: Understanding the past to intervene for the future

Cities, 46 (2015), pp. 67-75 
McCalla, 1997 A. McCalla

The water, food, and trade nexus

MENA-MED conference, World Bank, Marrakesh, Morocco (1997)

McCann, 2010 E. McCann

Urban policy mobilities and global circuits of Knowledge: Toward a research agenda

Annals of the Association of American Geographers, 101 (2010), pp. 107-130

McCormick et al., 2013

K. McCormick, S. Anderberg, L. Coenen, L. Neij

Advancing sustainable urban transformation

Journal of Cleaner Production, 50 (2013), pp. 1-212

McPhearson et al., 2015

T. McPhearson, E. Andersson, T. Elmqvist, N.Frantzeskaki

Resilience of and through urban ecosystem services

Ecosystem Services, 12 (2015), pp. 152-156

McPhearson et al., 2016

T. McPhearson, D. Haase, N. Kabisch, A. Gren

Advancing understanding of the complex nature of urban systems

Ecological Indicators, 70 (2016), pp. 566-573

Monstadt, 2009

J. Monstadt

Conceptualizing the political ecology of urban Infrastructures: Insights from Technology and urban studies

Environment and Planning A, 41 (2009), pp. 1924-1942

Moss, 2016

T. Moss

Unpacking and re-assembling the 'urban nexus': A socio-technical perspective on urban infrastructures

Nexuses of the urban: Interactions between water, energy, and food provision for sustainable cities (2016) Brighton, United Kingdom

Muller, 2015

M. Muller

The 'nexus' as a step back towards a more coherent water resource management paradigm

Water Alternatives, 8 (2015), pp. 495-675

Neirotti et al., 2014

P. Neirotti, A. De Marco, A.C. Cagliano, G. Mangano, F.Scorrano

Current trends in smart city initiatives: Some stylised facts

Cities, 38 (2014), pp. 25-36

O'Brien and Pike, 2017

P. O'Brien, A. Pike

The financialization and governance of infrastructure

E. Martin, J. Pollard (Eds.), Handbook on the geographies of money and finance chapter 10 (2017), pp. 223-252, Elgar

$\underline{\text { O'Flynn et al., } 2013}$ 
J. O'Flynn, D. Blackman, J. Halligan

Crossing boundaries in public management and Policy: The international experience

Routledge, Abingdon, Oxon (2013)

Parliamentary Office of Science \& Technology, 2016

Parliamentary Office of Science \& Technology

The water-energy-food nexus (2016)

http://researchbriefings.parliament.uk/ResearchBriefing/Summary/POST-PN$\underline{0543}$

Parnell, 2016 S. Parnell

Defining a global urban development agenda

World Development, 78 (2016), pp. 529-540

Perkins, 2009

H. Perkins

Out from the (Green) shadow? Neoliberal hegemony through the market logic of shared urban environmental governance

Political Geography, 28 (2009), pp. 395-405

Pitrenaite-Zileniene and Torresi, 2014

B. Pitrenaite-Zileniene, F. Torresi

Integrated approach to a resilient City: Associating social, environmental and infrastructure resilience in its whole

European Journal of Interdisciplinary Studies, 6 (2014), pp. 1-13

Pittock et al., 2015

J. Pittock, S. Orr, L. Stevens, M. Aheeyar, M. Smith

Tackling trade-offs in the nexus of water, energy and food

Aquatic Procedia, 5 (2015), pp. 58-68

Raco, 2011 M. Raco

The future of sustainable Cities: Critical reflections

Policy Press, Bristol, United Kingdom (2011)

Rittel and Webber, 1973

H.W.J. Rittel, M. Webber

Dilemmas in a general theory of planning

Policy Sciences, 4 (1973), pp. 155-169

Roelich et al., 2015

K. Roelich, C. Knoeri, J. Steinberger, L. Varga, P. Blythe, D. Butler, et al.

Towards resource-efficient and service-oriented integrated infrastructure operation

Technological Forecasting and Social Change, 92 (2015), pp. 40-52

Roelich et al., 2011

K. Roelich, J. Steinberger, C. Knoeri

Efficient and service oriented infrastructure operation; the role of the Energy

Efficiency Directive in driving change towards multi-utility service companies

ECEE 2011 Summer Study (2011)

Romero-Lankao et al., 2017

P. Romero-Lankao, T. McPhearson, D.Davidson

The food-energy water nexus and urban complexity

Nature Climate Change, 7 (2017), pp. 233-235 
J. Rutherford

Unbundling Stockholm: The networks, planning and social welfare nexus beyond the unitary city

Geoforum, 39 (2008), pp. 1871-1883

Schlor et al., 2017

H. Schlor, S. Venghaus, J.-F. Hake

The FEW-Nexus city index - measuring urban resilience

Applied Energy (2017), 10.1016/j.apenergy.2017.02.026

Schmid et al., 2016

C. Schmid, N. Brenner, M. Topalovic

Cartographies of planetary urbanisation

Kerb: Journal of Landscape Architecture, 24 (2016), pp. 92-93

Schmidt, 2015

V. Schmidt

Discursive institutionalism: Understanding policy in context

F. Fischer, D. Torgerson, A. Durnova, M. Orsini (Eds.), Handbook of critical policy studies, Edward Elgar Publishing Ltd (2015), pp. 171-189

Scollon, 2005

R. Scollon

The discourses of food in the world system: Toward a nexus analysis of a world problem

Journal of Language and Politics, 4 (2005), pp. 465-488

Scott et al., 2011

C.A. Scott, S.A. Pierce, M.J. Pasqualetti, A.L. Jones, B.E.Montz, J. Hoover

Policy and institutional dimensions of the water energy nexus

Energy Policy, 39 (2011), pp. 6622-6630

Serrao-Neumann et al., 2017

S. Serrao-Neumann, M. Renouf, S. Kenway, D. Low Choy

Connecting land-use and water planning: Prospects for an urban water metabolism approach

Cities, 60 (2017), pp. 13-27

Seto et al., 2010

K. Seto, R. Sanchez-Rodriguez, M. Fragkias

The new geography of contemporary urbanization and environment

Annual Review of Environment and Resources, 35 (2010), pp. 167-194

Sharifi and Yamagata, 2014

A. Sharifi, Y. Yamagata

Resilient urban planning: Major principles and criteria

Energy Procedia, 61 (2014), pp. 1491-1495

Smajgl et al., 2016

A. Smajgl, J. Ward, L. Pluschke

The water-food-energy Nexus - realising a new paradigm

Journal of Hydrology, 533 (2016), pp. 533-540

Stein et al., 2014

C. Stein, J. Barron, T. Moss

Governance of the nexus: From buzz words to strategic action perspective 
Nexus Network Think Piece Series 0003 Economic \& Social Research Council Swindon, U.K (2014)

Stirling, 2010 A. Stirling

Keep it complex

Nature, 468 (2010), pp. 1029-1031

Stone, 1989 D. Stone

Causal stories and the formation of policy agendas

Political Science Quarterly, 104 (1989), pp. 281-300

Szerszynski and Galarraga, 2013

B. Szerszynski, M. Galarraga

Geoengineering knowledge: Interdisciplinarity and the shaping of climate engineering research

Environment and Planning A, 45 (2013), pp. 2817-2824

Treemore-Spears et al., 2016

L.J. Treemore-Spears,

J.M. Grove, C.K.Harris, L.D. Lemke, C.J. Miller, K. Pothukuchi, et al.

A workshop on transitioning cities at the food-energy-water nexus

Journal of Environmental Studies and Sciences, 6 (2016), pp. 90-103

United Nations, 2015a

United Nations

Reconciling resource uses in transboundary basins: Assessment of the waterfood-energy-ecosystems nexus

Technical Report ECE/MP.WAT/46 United Nations Economic Commission for

Europe (2015)

United Nations, 2015b

United Nations

Report of the inter-agency and expert group on sustainable development goal indicators (2015)

http://unstats.un.org/unsd/statcom/47th-session/documents/2016-

2IAEG970SDGs-E.pdf, Accessed 16th Mar 2017

Vanham et al., 2016

D. Vanham, T.N. Mak, B.M. Gawlik

Urban food consumption and associated water resources: The example of

Dutch cities

Science of the Total Environment, 565 (2016), pp. 232-239

Varga, 2016

L. Varga

A scale perspective on the 'urban nexus': The integration of different scales of infrastructure system

Nexuses of the urban: Interactions between water, energy, and food provision

for sustainable cities (2016), Brighton, United Kingdom

Viitanen and Kingston, 2014

J. Viitanen, R. Kingston

Smart cities and green Growth: Outsourcing democratic and environmental resilience to the global Technology sector

Environment and Planning A, 46 (2014), pp. 803-819

Villamayor-Tomas et al., 2015 
S. Villamayor-Tomas, P. Grundmann, G.Epstein, T. Evans, C. Kimmich

The water-energy-food security nexus through the lenses of the value chain and the institutional analysis and development frameworks

Water Alternatives, 8 (2015), pp. 735-755

Villaroel Walker et al., 2014

R. Villaroel Walker, M. Beck, J. Hall, R. Dawson, O. Heidrich

The energy-water-food nexus: Strategic analysis of technologies for transforming the urban metabolism

Journal of Environmental Management, 141 (2014), pp. 104-115

Vince, 2015 J. Vince

Integrated policy approaches and policy failure: The case of Australia's

oceans policy

Policy Sciences, 48 (2015), pp. 159-180

Vine, 2008 E. Vine

Breaking down the silos: The integration of energy efficiency, renewable energy, demand response and climate change

Energy Efficiency, 1 (2008), pp. 49-63

Wachsmuth et al., 2016

D. Wachsmuth, D. Cohen, H. Angelo

Expand the frontiers of urban sustainability

Nature, 536 (2016), pp. 391-393

Waughray, 2011

D. Waughray

Water security: The water-energy-food-climate nexus

Island Press, London, United Kingdom (2011)

Wichelns, 2017

D. Wichelns

The water-energy-food nexus: Is the increasing attention warranted, from either a research or policy perspective?

Environmental Science \& Policy, 69 (2017), pp. 113-123

Williams et al., 2014

J. Williams, S. Bouzarovski, E. Swyngedouw

Politicising the nexus: Nexus technologies, urban circulation, and the coproduction of water-energy

Nexus Network Think Piece Series, 1 (2014), pp. 1-27

Wilson, 1982 J. Wilson

Broken windows

Atlantic Monthly, 249 (1982), pp. 29-38

World Business Council for Sustainable Development, 2014

World Business Council for Sustainable Development

Water, food and energy nexus challenges

Technical Report WBCSD Geneva, Switzerland (2014)

You, 2016 N. You

The contribution of innovation in urban resilience and sustainability to realizing the urban nexus 
F. Dodds, J. Bartram (Eds.), The water, food, energy and climate Nexus:

Challenges and an agenda for action chapter 6 , Routledge, Abingdon, United Kingdom (2016), pp. 93-104

Zhang, 2016 X. Zhang

The trends, promises and challenges of urbanisation in the world Habitat International, 54 (2016), pp. 241-252 